УДК 005:351/354(438)+351.861

Борисов Андрій,

ORCID iD 0000-0001-6858-0492

E-mail: niv1966@ukr.net

Литвиновський Свген,

ORCID iD 0000-0003-2127-8354

E-mail: doklytvynovsky@ukr.net

\title{
АНТИКРИЗОВИЙ МЕНЕДЖМЕНТ У РЕСПУБЛІЦ ПОЛЬЩА: ОГЛЯД ОСНОВНОГО ЗАКОНУ ТА ПРАКТИК ЙОГО ЗАСТОСУВАННЯ НА ТЕРИТОРІАЛЬНОМУ РІВНІ ДЕРЖАВНОГО УПРАВЛІННЯ
}

https://doi.org/10.32689/2618-0065-2021-2(8)-56-91

\begin{abstract}
Анотація. Непередбачуваність та швидка змінюваність сучасних загроз, їх глобальний характер роблять безпеку однією 3 найважливіших проблем сучасного та майбутнього світу. Запровадження європейських стандартів, інтеграції України в ЄС потребують перетворень всіх сфер українського суспільства. Такими перетвореннями в системі управління Єдиною державною системою цивільного захисту, враховуючи необхідність реалізації Концепції управління ризиками, $є$ необхідність розроблення механізмів державного регулювання у сфері управління ризиками. Однак впровадження на території України сучасних принципів антикризового менеджменту здійснюється повільними темпами. Науковцями, здійснюється спроба опрацювання новітніх організаційно-управлінських підходів до вирішення проблем управління ризиками виникнення надзвичайних ситуацій. Однак поза увагою залишився досвід організації кризового менеджменту в Республіці Польща (далі - РП), де основи його досить грунтовно визначені на законодавчому рівні, а практика впровадження його принципів сягає понад 13 років. Огляд Закону Республіки Польща «Про антикризовий менеджмент» та практики його застосування на територіальному рівні в частині розробки планів антикризового менеджменту є науковим завданням нашого дослідження і висвітлений в даній статті. Основним методом дослідження є контент-аналіз основного Закону РП «Про антикризове управління» та аналіз змісту планів антикризового управління. Також застосовувався літературний пошук публікацій польських вчених з антикризового менеджменту. В основному змісті статті: наголошується,що Концепція антикризового управління, яка закладена в Законі РП, зосереджена на принципі першості територіальної системи державного устрою; аналізується поняттєво-термінологічний апарат, визначений у ньому; аналізуються плани антикризового
\end{abstract}


менеджменту на воєводському рівні. У статті визначаються принципи побудови системи антикризового менеджменту, особливості системи кризового менеджменту на різних рівнях державного управління; робиться висновок про інтегрованість ऑї в систему національної безпеки, яка структурно має підсистеми управління, виконавчу підсистему і підсистему забезпечення; стверджується, що велика увага в системі антикризового менеджменту приділяється питанням організації співпраці, кризових комунікацій між всіма рівнями управління. Для цього створюється мережа безпеки, що $є$ актуальним для удосконалення системи в Україні. Функціонування системи, в першу чергу спрямована на запобігання виникнення кризових ситуацій, а в разі їх виникнення, - взяття під контроль ïx розвитку, на основі запланованих заходів, мінімізація і ліквідація наслідків та відновлення функціонування суспільства докризового стану. Ключовим елементом, що законодавчо визначено і структурно прописано в Законі є фаза підготовки системи антикризового менеджменту РП. Аналіз планів антикризового управління показує, що в них деталізовано прописуються всі загрози, операції щодо їх моніторингу, мінімізації, сили і засоби, порядок співпраці. Зміст планів національного, воєводського, повітського рівнів, рівня гміни і комунальний інтегрований в частині організації координації діяльності, надання допомоги і підтримки нижньому рівню управління. В інтересах кризового менеджменту можуть застосовуватися збройні сили РП, створюватися спеціальні групи із складу поліції, державної пожежної служби тощо. Враховуючи основний метод управління у системі кризового менеджменту - метод управління проектів, в планах розробляються модулі дій з запобігання і реагування за кожною загрозою. У висновках, зазначається, що домінантною складовою системи антикризового менеджменту є їі територіальний рівень управління, на якому відбувається ретельне планування, моніторинг загроз та підготовка сил і засобів. Напрямом подальшого дослідження $є$ компаративний аналіз систем антикризового менеджменту різних країн, вивчення кращих практик організації антикризового управління РП.

Ключові слова: антикризовий менеджмент, Закон Республіки Польща «Про антикризовий менеджмент», планування, мережа безпеки, модуль реагування, модуль моніторингу, Концепція управління ризиками, управління проектами.

Постановка проблеми. Непередбачуваність та швидка змінюваність сучасних загроз, їх глобальний характер роблять безпеку однією 3 найважливіших проблем сучасного та майбутнього світу. Однак зараз це стає все складніше, тому що динамічний культурний i цивілізаційний розвиток супроводжується змінами та переоцінкою викликів та загроз, 3 якими часто стикається міжнародна спільнота, включаючи 


\section{Науковий вісник : державне управління № 2(8) 2021}

польське й українське суспільство. Сьогодні все важче точно визначити суб'єкти, які є джерелом загроз (держава, організація чи соціальна група), умови та фактори їх функціонування стають все більш важливими для генерування потенційних загроз та районів їх виникнення. Результатом $\epsilon$ потреба в системних рішеннях для антикризового управління.

«Світ під тиском криз змінився. У світі наразі спостерігається хвиля війн, воєнних локальних конфліктів, масових протестів, кольорових революцій, політичних криз, торговельних та валютних війн. Старі моделі взаємодії та управління уже не працюють. Очевидно, що людство поки не дуже добре справляється 3 усіма цими кризами. Леді «невизначеність» стала головною у нашому сучасному житті» [1].

Запровадження європейських стандартів безпечної життєдіяльності, що є однією з вимог інтеграції України в ЄС, можливе за умови реалізації концептуальних і методологічних інновацій та інституціональних перетворень.

Такими перетвореннями в системі управління Єдиною державною системою цивільного захисту, ще у 2014 році, було визначено запровадження сучасних методів управління ризиками для зменшення кількості та мінімізації соціальноекономічних наслідків надзвичайних ситуацій, забезпечення досягнення гарантованого рівня безпеки громадянина i суспільства [2]. А їх шляхом - розроблення механізмів державного регулювання у сфері управління ризиками.

Але, як тоді, так і сьогодні, незважаючи на функціонування ЄДСЦЗ в режимі надзвичайної ситуації, впровадження на території України сучасних принципів антикризового менеджменту здійснюється повільними темпами.

Науковцями, наприклад із найсучасніших досліджень [3], здійснюється спроба опрацювання новітніх організаційноуправлінських підходів до вирішення проблем управління ризиками виникнення надзвичайних ситуацій. Однак поза увагою залишився досвід організації кризового менеджменту в Республіці Польща (далі - РП), де основи його досить грунтовно визначені на законодавчому рівні [4], а практика впровадження його принципів сягає понад 13 років. 
Огляд цього досвіду цікавий нам ще у напрямі пошуку підгрунтя щодо обгрунтування кластерно-ситуаційного методу організації кризових комунікацій між суб'єктами забезпечення цивільного захисту, який ми обгрунтовуємо у своїх дослідженнях (С. Литвиновський). Застосування цього методу передбачає виявлення загроз; створення кластерів безпеки, реєстрів загроз, складання оцінки ризиків, визначення негативного впливу на людей, майно, середовище та критичну інфраструктуру; визначення кластерів функціональних та структурно-організаційних проектів для підготовки центральної та місцевої адміністрації системи кризового менеджменту, а також державних ресурсів для реагування на актуальні загрози; визначення сценаріїв, яких слід дотримуватися у випадку кризових ситуацій; підготовка та обслуговування сил та засобів, які будуть використовуватися для запобігання (реагування) на кризу; визначення домінантного суб'єкта забезпечення цивільного захисту в тому чи іншому кластері; визначення дій $з$ координації між суб'єктами, залученими до реагування на кризи в тому чи іншому кластері тощо.

Особистий внесок авторів в публікації розподілено таким чином: ідея, критичний аналіз змісту Закону РП та джерельної бази, класифікація напрямів досліджень польських вчених 3 кризового менеджменту, висновки належать С. Литвиновський; пошук джерельної бази, оформлення анотацій - А. Борисову.

\section{Аналіз останніх досліджень і публікацій.} Євроінтеграційні процеси, які відбувається сьогодні у суспільному житті України, зрозуміло не залишають поза увагою аналіз практики трансформаційних перетворень нашого найближчого сусіда, який нещодавно став членом $Є С$ Республікою Польщею, що успішно здійснює перетворення систем державного регулювання, у тому числі і в сфері антикризового менеджменту.

Дотичними з цієї проблематики серед інших можна визначити дослідження українських науковців А. Рогулі, В. Чигринського, Є. Нікіпєлової [6-8]. Однак в прямій постановці проблематика антикризового управління в Республіці Польщі, зокрема, огляд основного Закону «Про антикризове управління»[4] не зустрічається. 


\section{Науковий вісник : державне управління № 2(8) 2021}

Досвід для України системи державного управління РП вивчався ще у 2010 році групою науковців під керівництвом Ю. Ковбасюка. [5]. Слід зауважити, що вже тоді, науковці звертали увагу на базовий принцип державного управління в РП - домінантність територіального рівня. Аналізуючи положення Конституції РП науковці зазначають «“Територіальне самоврядування" надзвичайно важливе, оскільки воно стосується принципу субсидіарності... (окрема стаття Конституції - Є. Литвиновський) визначає принципи, 3 яких випливають орієнтовні компетенції гміни - “основної одиниці територіального самоврядування” [5, с. 6]. Як ми побачимо при подальшому аналізі Закону «Про антикризове управління» - цей принцип простежується i в системі антикризового менеджменту РП.

А. Рогуля, аналізуючи систему цивільного захисту РП, зазначає на розгалуженості органів управління (Головна комендатура пожежної охорони, Служби водного та гірського порятунку, Цивільна оборона а також їх підрозділи на регіональному та місцевому рівнях, які підпорядковані місцевим органам влади). Автор вказує, що загальну координацією цієї роботи здійснює орган центральної виконавчої влади Міністерство внутрішніх справ i адміністрації, у структурі якого діють, зокрема, Бюро з питань ліквідації наслідків стихійних лих і Департамент кризового управління та оборонних справ, аналізує функції Департаменту кризового управління та оборонних справ [6, с. 134].

Однак, в дослідженні на зазначений Закон уваги не звертається, не визначається специфіка системи національної безпеки РП, в якій система антикризового менеджменту, за аналізом праць польських науковців, визначається окремою складовою (підсистемою).

В. Чигринський на основі аналізу стратегічних документів 3 питань національної безпеки та суспільного розвитку РП констатує, що їх розробка здійснювалася в рамках теорії національної безпеки, у тому числі на основі концепцій: прийнятного ризику, яка $\epsilon$ основою для раціонального планування заходів щодо забезпечення національної безпеки 3 урахуванням соціально-економічних чинників; виправданого 


\section{Науковий вісник : державне управління № 2(8) 2021}

ризику, згідно якої прийнятним ризиком вважається той ризик, що суспільство виправдовує заради гарантування національної безпеки; стратегічних ризиків, що має гарантувати безпеку людини, суспільства та держави, а також сталий розвиток держави в умовах глобальних викликів та транскордонних загроз національним інтересам [7, с.46].

Є. Нікіпєлова, досліджуючи державне управління безпековою політикою РП, зазначає, що стратегічні інтереси визначають стратегічні цілі у сфері безпеки, до яких відносяться: вдосконалення інтегрованої системи національної безпеки, особливо ії елементів управління, включаючи забезпечення необхідними ресурсами й можливостями; забезпечення національної безпеки через вдосконалення рятувальної та пожежної систем, системи моніторингу та повідомлення щодо попередження про загрози та ліквідацію наслідків стихійних лих, а також здійснення юридичних та організаційних рішень у сфері цивільного захисту та цивільної оборони [8].

Перелічені вище пріоритети передбачають серед стратегічних дій у сфері безпеки і проведення рятувальних операцій, врегулювання кризових ситуацій [9].

$€$ С. Нікіпєлова зазначає, що система національної безпеки включає: 1) підсистема управління; 2) виконавчі підсистеми; 3) підсистеми забезпечення. Головним завданням підсистеми управління є забезпечення прийняття та виконання важливих рішень та дій з метою збереження національної безпеки. Крім того, на цю підсистему покладені завдання, пов'язані 3 відстеженням джерел, видів, напрямів і масштабності загроз. До виконавчих підсистем відносять інструменти, які $\epsilon$ у розпорядженні органів управління, призначені для виконання завдань у сфері національної безпеки, забезпечуючи зовнішню і внутрішню безпеки країни. Основним завданням виконавчих підсистем є раннє прогнозування і запобігання загрозам безпеки країни, а в разі їх настання - протидія негативним наслідкам. Підсистемами забезпечення вважаються всі інші сили і засоби держави, що застосовуються на додаток до своєї основної функції та приймають безпосередню участь у забезпеченні безпеки в різних формах [8]. 


\section{Науковий вісник : державне управління № 2(8) 2021}

Забігаючи вперед, можемо зазначити, враховуючи інтегрованість системи антикризового менеджменту РП в систему національної безпеки, Закон [4] чітко визначає таку ж іiі структуру: органи управління, виконавча підсистема, підсистема забезпечення.

Отже, серед науковців України аналіз системи антикризового менеджменту розглядався, як складова системи цивільного захисту, національної безпеки в цілому. Окремих досліджень 3 специфіки антикризового менеджменту в РП, принаймні нам не відомі.

Зрозуміло, що аналізу системи антикризового менеджменту РП присвячена низка досліджень польських науковців.

Причиною виникнення та динамічного розвитку антикризового управління в Республіці Польщі (J. Falecki) стало розуміння того, що протидія сучасним загрозам безпеці, що характеризуються непередбачуваністю, насильством, багатовимірністю, мінливістю, невизначеністю та взаємним проникненням, та обмеження потенційних збитків вимагає безпосередньої участі влади, використання різноманітних сил та засобів, якими володіє держава.

Фундаментальним дослідженням 3 питань антикризового управління можна вважати дослідження J. Falecki «Дилеми антикризового менеджменту». Науковцем проведений критичний аналіз літератури 3: теоретичних основ антикризового управління, визначення предмету (змісту) антикризового управління та його місця в системі національної безпеки, аналізу стану системи антикризового управління в Польщі, досвіду окремих країн, а також НАТО та ЄС у галузі антикризового управління [10].

Науковець зазначає, що дослідження антикризового управління повинні стосуватися етапів запобігання, готовності, реагування, відновлення та, зокрема, включати такі проблемні сфери, як: виклики та загрози, правові рішення, організаційні структури системи, планування, процес прийняття рішень, організація співпраці, координація діяльності, організація та проведення тренінгів, збір та обмін досвідом, наслідки халатності та бездіяльності, поведінка людей у кризових ситуаціях, можливості обмеження наслідків кризових ситуацій 


\section{Науковий вісник : державне управління № 2(8) 2021}

або сфери компетенції та відповідальності посадових осіб. Перевірені результати наукових досліджень повинні використовуватися законодавчими органами, центральною та місцевою адміністрацією, елементами системи антикризового управління та органами виконавчої влади, а також університетами та школами.

Пошуковий аналіз реферативних наукових баз свідчить, що за зазначеними напрямами в РП проводиться доволі багато досліджень.

Виклики та загрози досліджуються в працях P. Swoboda, K. Sienkiewicz-Małyjurek, U. Kąkol, M. Marczewski, M. Kisilowski, G. Kunikowski, J. Stawnicka I. Klonowska [11-16],

«De lege lata i de lege ferenda» законодавства (аналіз існуючого i бажаного) в сфері антикризового менеджмента розглядає K. Płonka-Bielenin [17].

Проблематиці удосконалення організаційних структур антикризового менеджменту присвячені праці K. SienkiewiczMałyjurek, M. Kopczewski, K. Górska, K. Korzecki, W. Pączek, Gr. Gorski, A. Potoczky [18-22].

Методики та інструментарій антикризового менеджменту досліджують Gr Kunikowski, J. Smagowicz, A. Uklańs [23].

Процеси прийняття рішення розглянуті у працях Zb. Ciekanowskogo, A. Marjańskogo, K. Sienkiewicz-Małyjurek $[24,25]$.

Велика когорта науковців, що доводить важливість проблематики, досліджують організацію співпраці, координацію діяльності різних суб'єктів мережі безпеки, їх ролі та функцій. Серед них, В. Wiśniewski, J. Prońko, A. Żebrowski, A. Morawski, M. Beskosty, A. Marjański, Ja. Ropęga, P. Derek, O. Zwierkowska [26-32].

Важливим джерелом для вдосконалення системи антикризового управління польські науковці вважають досвід країн, які вже побудували такі системи, використовуючи їх для забезпечення безпеки своїх громадян, а також впроваджуючи необхідні інновації. Так, M. Banasik вивчає досвід антикризового управління НАТО як механізм забезпечення безпеки та захисту населення [33].

Поведінка людей у кризових ситуаціях досліджується 


\section{Науковий вісник : державне управління № 2(8) 2021}

Świderski Andrzej W., Chrzan T., Chodyński Andrzej [34-36].

Організація та проведення тренінгів - ще одна тематика наукових досліджень польських науковців. Зокрема, дослідження Pawłuszko Tomasza [37] присвячено проблемі проектування підручників для навчання, у тому числі в системі антикризового менеджменту. А розлога публікація J. Faleckogo [38] може бути настільною книгою науково-педагогічних працівників, не тільки щодо організації навчання органів управління єдиної державної системи цивільного захисту України, а й для усвідомлення специфіки організації системи антикризового управління у РП.

Публікація J. Faleckogo [38] висвітлює не тільки теоретичні та практичні аспекти підготовки та проведення гри 3 прийняття рішень у галузі антикризового управління, а й розкриває проблеми планування в системі антикризового управління 3 його сутністю, принципами планування, обов'язковими плановими документами. Також в ній розкрита концепція процесу прийняття рішень під час кризової ситуації, яка знайомить учасників гри у прийнятті рішень 3 фазами, етапами та діями, що виконуються під час цього процесу. Важливе місце в публікації займає каталог загроз, який є основою для розробки завдань та зобов'язань учасників антикризового управління у вигляді територіальної мережі безпеки. А зразковий варіант прийняття рішення, який базується на реальних умовах району Заверце і який враховує особливості цього району, загальну та конкретну ситуацію, основні сили та ресурси, алгоритм «Робота Повітської групи з управління кризисними ситуаціями у разі повені та забруднення нафтовими речовинами» може бути практикою, яку необхідно додатково вивчити.

Ще одним дослідженням, на яке ми звернули увагу з метою підтвердження висунутої гіпотези щодо ефективності застосування розробленого нами кластерно-ситуаційного методу побудови системи цивільної безпеки суспільства та яке підтверджує базовий принцип побудови системи антикризового менеджменту РП - домінантність іiі територіального рівня, $\epsilon$ публікація з презентації Карти загроз національної безпеки, описаної J. Stawnicka та I. Klonowska [39].

Вивчення цього проекту $\epsilon$ ще важливим в частині 
визначення головного фактору безпеки - відповідальності кожного громадянина і громади за рівень небезпек в місцях проживання. Проект пов'язаний із заходами, що формують соціальну свідомість у сфері відповідальності за стан безпеки в місцевих громадах. Оскільки почуття безпеки $є$ основною, екзистенціальною i, безумовно, найважливішою потребою кожної людини, зазначають автори [39], міністерство внутрішніх справ РП, зокрема Поліція як одна 3 ключових інституційних установ Республіки Польщі, що входить суб'єктом в мережі безпеки системи антикризового менеджменту на всіх рівнях, розробило інструмент для співпраці 3 громадами - локальні карти із зазначенням масштабу та типу загроз, ідентифікованих установами, що відповідають за безпеку та громадський порядок.

Відповідно до припущення проекту, одержувачем інформації $\epsilon$ громадськість, а інформація, отримана від громадськості, $є$ джерелом щодо виявлення (підтвердження) наявних небезпек в конкретному місці і в конкретний час. Карти загроз цивільній безпеці та громадському порядку - це складені списки загроз життю, здоров'ю та майну людей 3 урахуванням їх розподілу в просторі та часі. Національна карта загрози безпеці - це сучасна система зв'язку, якою користується все більше жителів. Таким чином, мешканці мають реальний вплив на підвищення безпеки, а органи управління безпекою відчувають підтримку місцевої громади. Це дозволяє, з одного боку, підвищити почуття безпеки, з іншого боку, це формує довіру до органів влади та заохочує співпрацю 3 ними та в цілому $є$ інструментом побудови громадянського суспільства. Національна карта загроз безпеці - це також цінний інструмент у формуванні освітньої ролі органів влади та реального залучення громадян до формування цивільної безпеки та громадського порядку.

Отже, база досліджень з антикризового менеджменту в Республіці Польща досить велика та вимагає додаткового дослідження. Окремого аналізу потребують документи планування, що на рівні воєводства мають великий обсяг (до 800 стор.), тексту, таблиць, схем [40,41].

J. Falecki, на основі літературного аналізу, дійшов 


\section{Науковий вісник : державне управління № 2(8) 2021}

висновку, що серед науковців РП не існує однозначності у визначенні основних понять антикризового управління, таких як: криза, кризова ситуація, загроза системі антикризового управління. Дискусії щодо обсягу завдань, структур та діяльності системи антикризового управління в Польщі практично продовжуються. Деякі науковці розглядають антикризове управління та його систему як протиотруту від загроз із каталогу стихійних лих, наслідки яких загрожують життю чи здоров'ю великої кількості людей, майну чи навколишньому середовищу, а допомога та захист можуть бути ефективно здійснені лише 3 використанням надзвичайних заходів. Інша велика група прихильників тлумачить антикризове управління дуже широко - як управління національною безпекою (система національної безпеки) в кризових ситуаціях» [42]. Третя ставиться до антикризового управління більш вузько - як до виконання завдань цивільного захисту.

На думку J. Falecki, у чому ми його підтримуємо, суть антикризового управління полягає не тільки у реагуванні на можливу кризову ситуацію, але, що саме головне, в організації заходів, спрямованих на запобігання виникненню таких ситуацій [10].

Тобто, поряд 3 реагуванням та відновленням стану суспільства до кризової ситуації, увага звертається, насамперед, на створення системи запобігання виникнення кризових ситуацій. Чому, більшість вчених розуміють дефініцію «zarządzania kryzysowego» «crisis management» як антикризове управління, а кризовий менеджмент, в нашому розумінню для польських вчених - це управління під час реагування та ліквідації наслідків кризової ситуації (надзвичайної ситуації). У даному випадку англійськім відповідником може буде «emergency management».

Щодо визначення термінології в розумінні польських та інших європейських науковців - це окрема тема дослідження, якій буде присвячена окрема публікація, як і глибинному критичному аналізу наукових досліджень польських вчених 3 питань розвитку та удосконалення системи антикризового менеджменту. Адже, як зазначає J. Falecki, система 
антикризового управління є відносно новим елементом у галузі безпеки, що динамічно розвивається, піддається змінам та вдосконаленням під час свого функціонування та що $\epsilon$ надзвичайно важливим - не до кінця визначеною. Тому, надзвичайно важливо проводити дослідження для вироблення гіпотез щодо іiї вдосконалення [10].

Узагальнюючи результати аналізу публікацій польських науковців з антикризового управління, важливо зазначити, що основними факторами ефективності системи антикризового управління, з чим ми не можемо не погодитися, визначаються: відповідні правові норми; ефективні рішення та організаційні зв'язки; відповідні компетенції ключових стейхолдерів системи; належна розробка планів антикризового управління, що містять сили та засоби, які можна використовувати у кризовій ситуації; операційні процедури, методи вирішення гіпотетичних кризових ситуацій; принципи координації діяльності та організації співпраці або моніторингу для забезпечення своєчасної, повної та достовірної інформації про загрози. Крім того, важливим фактором є систематичне навчання керівництву системою та координації всіх ii елементів, а також вмінню приймати точні та своєчасні рішення [43].

Саме огляду правових норм, а саме огляду основного закону Польщі «Про антикризове управління» [4] та належній розробці планів антикризового управління на рівні домінантних утворень мережі безпеки - територіальних громад і буде присвячена дана стаття. Деякі із положень Закону будуть посилені коментарями польських вчених, для більш якісного їх розуміння, пояснюють законодавчо визначені засади кризового менеджменту в РП та підтверджують науковість їх обгрунтування.

Мета статті : огляд Закону Республіки Польща «Про антикризовий менеджмент» та практики його застосування на місцевому рівні в частині розробки планів антикризового менеджменту.

Методи дослідження. Основним методом дослідження $\epsilon$ контент-аналіз основного Закону РП «Про антикризове управління» та критичний аналіз змісту планів антикризового управління. Також застосовувався джерельний пошук 


\section{Науковий вісник : державне управління № 2(8) 2021}

публікацій з проблематики статті.

Виклад основного матеріалу. Найважливішою підсистемою, що функціонує в системі національної безпеки РП, є підсистема антикризового управління [10]. Системний підхід дозволяє трактувати широке поняття антикризового управління як внутрішньо скоординовану систему сил, ресурсів та засобів, що застосовуються державою та суспільством для: запобігання надзвичайним ситуаціям, підготовці до контролю над нею через заплановані заходи, ефективної реакції у разі їх виникнення, відновлення / реконструкції та відновлення функціонування критичної інфраструктури. [44, с. 65].

Наші польскі колеги G. Sobolewski, M. Sikora чітко визначають специфіку сучасної системи антикризового управління. «Прогнозування та аналіз загроз стають однісю 3 найбільш пріоритетних галузей знань, оскільки вони тісно пов'язані із безпекою, в деякому сенсі вони є ії̈ синонімом» [42].

Отже, чітко простежується, і це ми побачимо далі при аналізу Закону, пріоритетним завданням системи антикризового менеджменту РП є завдання запобігання та мінімізації ризиків виникнення кризових (надзвичайних) ситуацій.

Аналіз Закону свідчить, що система антикризового управління РП складається насамперед із органів державного управління як елементів управління національною безпекою в цілому. В Законі визначені повноваження, у тому числі i збройних сил РП, особливість їх застосування для вирішення завдань «внутрішньої безпеки». Також в систему входять виконавчі елементи системи національної безпеки (виконавча підсистема антикризового управління). Зауважимо ще раз про прагнення створення в РП інтегрованої системи безпеки.

Концепція антикризового управління, яка закладена в Закон, зосереджена на принципі першості територіальної системи, тобто основний тягар прийняття рішень та відповідальності лежить на владі, яка функціонує на певному рівні територіального поділу країни, в якій сталася криза.

Виконавча підсистема включає служби, охорону, інспекції у формі людських ресурсів та технологій (засобів). Елементи цієї підсистеми складають важливий виконавчий ресурс, без якого навіть найскладніші системи прийняття рішень та органи, 
відповідальні за безпеку, не змогли б виконати свої статутні завдання. У кризовому управлінні їх роль виявляється в організованому співробітництві, дотриманні принципів, що формують їх роботу та співпрацю у вирішенні кризових ситуацій [44, с. 77].

Вирішення кризової ситуації вимагає спеціальних дій та часто додаткових зусиль та ресурсів, тому важливим елементом кризового менеджменту, що простежується головною думкою через весь Закон є організація кризових комунікацій і допомоги між різними складовими системи кризового менеджменту.

У разі виникнення конкретної загрози та кризової ситуації буде активовано відповідний елемент виконавчої підсистеми національної безпеки. Найчастіше для цього знадобиться співпраця багатьох суб'єктів. Для цього на окремих рівнях системи $\epsilon$ відповідні ресурси для виконання завдань 3 антикризового управління, включаючи: невідкладна та медична допомога, пожежна служба; правоохоронні служби (поліція, міська варта); інспекції та інші організації [44, с. 74].

Польські вчені зазначають, що система антикризового управління все ще має багато слабких елементів. Однак аналіз положення Закону дозволяє простежити формування чіткої системи з їі взаємозв'язками, рівнями відповідальності та саме головне, що важливо при формуванні мережі безпеки і в Україні, організацією взаємодії і кризових комунікацій.

Згідно із ст. 2 зазначеного Закону Управління кризовими ситуаціями (антикризове управління) - це діяльність органів державного управління що с елементом управління національною безпекою, яка включає запобігання кризам, підготовку до реагування, контроль над ними за допомогою запланованих дій, реагування на випадок аварій (надзвичайних ситуацій), усунення їх наслідків та відновлення критичної інфраструктури [4, ст. 2].

Варто зазначити, що в кризовій ситуації ключове значення має узгоджена та однозначна термінологія. I хоча серед польських вчених, як зазначалось вище, немає однозначної визначеності в категоріально-поняттєвому апараті антикризового менеджменту, але доцільно звернути на деякі законодавчо визначені поняття [4, ст. 3]. 


\section{Науковий вісник : державне управління № 2(8) 2021}

Кризова ситуація - ситуація, яка негативно впливає на рівень безпеки людей, майно значних розмірів чи навколишнє середовище, спричиняючи значні обмеження в роботі компетентних органів державного управління через недостатню кількість наявних у них сил та ресурсів;

Карта небезпеки - карта із зазначенням географічної зони, що охоплюється діапазоном небезпеки, 3 урахуванням різних типів сценаріїв подій. Карта ризику - карта чи опис, що представляє потенційно негативний вплив загрози на людей, навколишнє середовище, майно та інфраструктуру.

Мережа безпеки - перелік потенційних загроз із зазначенням провідної організації у їх усуненні та суб'єкти, що 3 ним координують діяльність.

Планування - організаційні заходи, спрямовані на підготовку державного управління для антикризового управління.

Цикл планування - періодична реалізація етапів: аналізу, програмування, розробки плану чи програми, його реалізації, тестування та запуску.

Необхідно зазначити, що на нашу думку, яка склалася при аналізі законодавчих положень, наукових праць польських вчених, в РП визначено, що суспільство постійно знаходиться в ситуації мінімальної небезпеки (ситуації невизначеності). Метою органів державного управління всіх рівнів є запобігання переходу цієї ситуації в активну фазу - кризу (кризову ситуацію), мінімізація можливостей такого переходу. А в разі, все ж таки, іï виникнення, опанування контролю над нею завдяки запланованим заходам та реагування 3 метою якнайшвидшого відновлення первинного стану. Тому, ключовим елементом, що законодавчо визначено і структурно прописано в Законі, є фаза підготовки системи антикризового менеджменту РП.

Вона полягає в розробці планів реагування на кризи. Метою ïx $€$ чітке визначення функціонально-оперативних зв'язків між органами управління та силами. Ці плани описують хто, що i коли буде робити, якими силами та засобами та на якій нормативно-правовій основі (до, під час і безпосередньо після кризової події). Підготовка також забезпечує ресурси 


\section{Науковий вісник : державне управління № 2(8) 2021}

спеціалізованих сил та засобів реагування, наприклад: органи управління та їх розташування, система кризових комунікацій, оповіщення та персонал з реагування на кризи, а також електронні ресурси сил та ресурси, корисні для реагування на кризу.

Принципи побудови системи антикризового менеджменту РП:

універсальність - антикризове управління організовується органами державної влади у співпраці 3 існуючими спеціалізованими установами та організаціями, а також широкою громадськістю [45];

домінантність територіальної системи. Основою побудову моделі кризового менеджменту $\epsilon$ територіальна система держави. Це правило зводить до допоміжної функції галузеву систему держави;

вірогіднісна категоризація загроз - вона полягає у поділі загроз на групи за типом та розміром та призначення ним конкретних правових, організаційних та фінансових рішень щодо мінімізації, реагування на виникнення, ліквідації наслідків та відновлення функціонування.

Основним методом управління в системі антикризового менеджменту РП визнається метод управління проектами (набір проектів ст. 5 Закону [4]). Під проектом розуміється конкретні заходи щодо зменшення ймовірності виникнення кризової ситуації за певною загрозою, а також, у разі iї виникнення, прийняття заходів щодо опанування ситуацією та відновлення нормального стану функціонування об’єкту, території, суспільства.

Сукупність цих проектів включаються в плани антикризового управління відповідного суб'єкту. В системі антикризового планування, що важливо взяти до уваги в Україні, належним чином деталізовано визначено порядок організації взаємодії між органами та силами, що залучаються (надалі виділено курсивом).

Далі наводиться переклад статті Закону, що присвячена плануванню 3 метою доведення тези про конкретність i визначеність законодавством РП організації системи антикризового менеджменту на всіх рівнях державного 


\section{Науковий вісник : державне управління № 2(8) 2021}

управління, при умові короткого змісту Закону (35 статей). Зміст антикризового менеджменту можна проаналізувати вже на основі статті, що присвячена плануванню.

Згідно ст. 5 Закону [4] розробляється Національний план антикризового управління та плани антикризового управління воєводством, повіту та гміни (громади), далі - «Плани антикризового управління».

Плани антикризового управління включають 1) генеральний план, що містить:

характеристики загрози та оцінка ризику, у тому числі критичній інфраструктурі, а також карти ризику та загрози;

завдання та обов'язки учасників антикризового менеджменту у вигляді мережі безпеки;

перелік сил та ресурсів, які планується використовувати у кризових ситуаціях;

завдання, визначені у відповідних короткострокових планах дій з охорони навколишнього середовища.

2) набір проектів у разі кризи, включаючи:

завдання у сфері моніторингу загроз;

режим мобілізації необхідних сил та ресурсів, щзо беруть участь у реалізації запланованих проектів на випадок кризи;

процедури реагування на надзвичайні ситуачії, щуо конкретизують способи подолання надзвичайних ситуацій;

співпрачя між силами, зазначеними вище;

3) функціональні додатки до генерального плану із зазначенням:

процедури виконання завдань у сфері антикризового управління, включаючи ті, що стосуються захисту критичної інфраструктури;

організація комунікацій;

організація системи моніторингу загроз, попередження та оповіщення;

правила інформування громадськості про загрози та що робити у випадку загроз,

організація евакуації з небезпечних районів;

організачія екстрених служб, медичної допомоги, сочіальної допомоги та психологічної допомоги;

організація захисту від загроз, характерних для даної 
Науковий вісник : державне управління № 2(8) 2021

місцевості;

перелік укладених договорів та угод, пов'язаних 3 виконанням завдань, що містяться в плані антикризового управління;

правила та порядок оцінки та документування збитків;

процедури мобілізаџї державних резервів;

перелік критично важливої інфраструктури, розташований у воєводстві, повіті чи комуні, на який поширюється план антикризового управління;

пріоритети щодо захисту та відновлення критичної інфраструктури.

Плани антикризового управління підлягають систематичному оновленню та цикл планування не може бути довше двох років. Цикл планування повинен здійснюватися компетентними органами державного управління та суб'єктами, що передбачають реалізацію проектів, визначених планом в обсязі їх залучення. Плани антикризового управління узгоджуються 3 керівниками організацій, які планується використовувати для виконання проектів, визначених планом.

Отже, iз аналізу структурних елементів плану антикризового управління можна чітко визначитися 3 елементами системи, їх повноваженнями, структурними взаємозв'язками. Враховуючи структурний аспект, плани кризового управління на всіх рівнях - це сукупність документів: аналізи, таблиці, дослідження, вказівки, списки, інструкції чи сценарії, які розробляються в хронологічному порядку, створюючи єдине ціле. Їх основна функція забезпечення узгодженої роботи всіх можливих елементів, що виникають у певній області в процесі управління кризовими ситуаціями. Про ступінь деталізації планів можна судити на основі аналізу конкретних планів антикризового управління на рівні воєводства, які містять понад 800 с. [40, 41].

Основою планування антикризового управління на будьякому рівні територіального устрою Польщі розробляється моніторинговий документ - «Рапорт про загрози національній безпеці» (Звіт) [4, ст. 5а]. Звіт містить: карту ризиків (вказівка найважливіших загроз), визначення стратегічних цілей, визначення пріоритетів у реагуванні на конкретні загрози; 


\section{Науковий вісник : державне управління № 2(8) 2021}

вказівка сил і засобів, необхідних для досягнення стратегічних цілей; завдання програмування 3 метою підвищення безпеки 3 урахуванням регіональних та місцевих можливостей; додатки, що містять ієрархічно упорядкований перелік проектів (модулів), необхідних для досягнення стратегічних цілей. На основі аналізу змісту Звіту можна констатувати, що він обгрунтовано відповідає на такі питання: Що може статися? Яка ймовірність того, що це станеться? Якими будуть наслідки? Оцінка наслідків несприятливої події $є$ особливо важливим елементом процесу антикризового управління, який $\epsilon$ визначальним фактором для прийняття рішень, спрямованих на захист життя та здоров'я населення. Поєднання частоти (ймовірності виникнення) та аналізу ефектів, що називається оцінкою ризику, дає відповідь на питання, чи існує існуючий ризик у прийнятних межах. Якщо ризик виходить за ці межі, слід вжити заходів для зниження ризику до прийнятного рівня шляхом введення необхідних гарантій його зниження.

На основі аналізу публікацій польських науковців, що наведені у списку використаних джерел, визначено особливість вимог до планів антикризового управління. До основних вимог відносяться:

Комплексність, що складається з врахування всіх можливих загроз, які можуть виникнути в даній сфері, та включаючи всіх суб'єктів, які беруть участь у запобіганні, реагуванні та ліквідації наслідків.

Функціональні можливості, що полягають у забезпеченні корисності плану у всіх ситуаціях та визначенні постійних функцій суб'єктів кризового управління на всіх етапах антикризового управління.

Корисність (вживаність), що полягає у прийнятті єдиної структури планів та форми детальних документів та забезпеченні простоти використання планових документів у разі різних подій.

Принципи планування: досяжність мети; реалістичність (слід використовувати лише наявні сили та ресурси, а завдання визначати для них на рівні їх спроможності); принцип своєчасності; принцип повноти (планування повинно давати відповіді на всі можливі, раніше створені події та визначати 
суворі завдання для всіх функціональних елементів); принцип ієрархії завдань (кожен суб'єкт та рівень управління відповідають за свою частину завдання); принцип гнучкості (можливість внесення змін у відповідь на непередбачену ситуацію); принцип перспективи (можливість використання запланованих дій для досягнення довгострокових цілей).

Важливе застереження польських вчених, яке не враховано в процесі планування в Україні, всі організації, які працюють в системі, повинні бути залучені до планування, а процес планування повинен відбуватися в контексті конкретного середовища. Якщо менеджери (управління кризою та реагування на кризу) цього не розуміють, вони не зможуть розробляти ефективні плани.

У табл. 1 наведена специфіка (особливості) антикризового управління на різних рівнях територіального устрою Польщі.

Таблиця 1 - Специфіка завдань антикризового менеджменту РП

\begin{tabular}{|c|c|c|c|}
\hline \multicolumn{4}{|c|}{ Рівень управління } \\
\hline $\begin{array}{c}\text { Національний } \\
\text { рівень }\end{array}$ & восводства & повіт & гміна \\
\hline $\begin{array}{l}\text { координація } \\
\text { діяльності, } \\
\text { співпраця з } \\
\text { Збройними силами } \\
\text { Польщі, } \\
\text { співпраця із } \\
\text { сусідніми країнами, } \\
\text { міжнародна } \\
\text { допомога, } \\
\text { фінансова допомога } \\
\text { потерпілим } \\
\text { виділення ресурсів } \\
\text { із державного } \\
\text { резерву }\end{array}$ & $\begin{array}{l}\text { координація } \\
\text { діяльності, } \\
\text { надання підтримки } \\
\text { на центральному } \\
\text { рівні, } \\
\text { співпраця } 3 \\
\text { Збройними силами } \\
\text { Польщі, } \\
\text { співпраця } 3 \\
\text { сусідами, } \\
\text { міжнародна } \\
\text { допомога } \\
\text { прикордонним } \\
\text { воєводствам }\end{array}$ & $\begin{array}{l}\text { координація } \\
\text { діяльності, } \\
\text { виділення } \\
\text { повітських сил, } \\
\text { надання } \\
\text { підтримки рівня } \\
\text { воєводства, } \\
\text { співпраця з } \\
\text { сусідами, } \\
\text { оцінка втрат на } \\
\text { рівні Повіту }\end{array}$ & $\begin{array}{l}\text { безпосередня } \\
\text { ліквідація } \\
\text { наслідків події, } \\
\text { організація } \\
\text { допомоги } \\
\text { постраждалому } \\
\text { населенню, } \\
\text { надання } \\
\text { підтримки рівня } \\
\text { повіт, } \\
\text { співпраця з } \\
\text { сусідами, } \\
\text { оцінка втрат на } \\
\text { рівні Гміни }\end{array}$ \\
\hline
\end{tabular}

Аналіз (табл. 1) переконливо підтверджує домінантність територіальної одиниці в системі антикризового менеджменту.

Як і в законодавстві України, в Законі РП виписані повноваження керівництва системи антикризового управління. Однак, в законі РП визначено урядову групу антикризового 


\section{Науковий вісник : державне управління № 2(8) 2021}

менеджменту та іï завдання (ст. 8, 9), завдання суб'єктів антикризового менеджменту (ст. 12), завдання воєвод (ст. 14), старост (ст. 17), завдання війтів, бурмистрів, президентів міст (ст. 19). Однак, у кожного суб'єкта антикризового менеджменту, на противагу від України, законодавчо визначений інституційний орган управління та його повноваження - центри антикризового управління. Їх повноваження визначаються законом. Так, відповідно до ст. 16 створюються воєводські центри управління кризисними ситуаціями, обслуговування яких здійснюється організаційними підрозділами, компетентними для управління кризисними ситуаціями у воєводських управліннях.

Завдання воєводських центрів управління кризисними ситуаціями включають:

цілодобове чергування для забезпечення потоку інформації для цілей антикризового менеджменту;

співпрачя з иентрами управління кризисними органами органів державного управління;

нагляд за функціонуванням системи виявлення та сигналізації та системи раннього попередження населення;

співпраця 3 суб'єктами, що здійснюють моніторинг довкілля;

співпраця 3 організаціями, що проводять рятувальні, розшукові та гуманітарні акції;

документування діяльності, що здійснюється центром;

виконання постійних чергових завдань з метою підвищення обороноздатності держави.

Специфікою Закону РП є те, що він визначає повноваження Збройних Сил РП в системі антикризового управління, а також спеціально створених груп із складу поліції, пожежної безпеки, солдат.

Так ст. 25 Закону [4] визначає: якщо в кризовій ситуації використання інших сил i засобів неможливе або може виявитись недостатнім, якщо іншими нормативними актами не передбачено інше, міністр національної оборони на прохання воєводи може надати в його розпорядження субодиниці або підрозділи Збройних сил Республіки Польща, разом із направленням їх на виконання завдань у сфері антикризового 
управління.

Підрозділи Збройних Сил можуть брати участь у виконанні завдань 3 врегулювання кризових ситуацій, відповідно до їх підготовки, відповідно до воєводського плану антикризового управління. Їх завданнями можуть бути участь у моніторингу загроз; виконання завдань, пов'язаних 3 оцінкою наслідків явищ, що відбуваються в зоні виникнення загроз; виконання пошуково-рятувальних завдань; евакуація постраждалого населення та майна; виконання завдань, спрямованих на підготовку умов для тимчасової присутності евакуйованих людей у відведених місцях; участь в охороні майна, що залишилось у зоні загроз; ізоляція району виникнення загроз або місця проведення рятувальної операції; виконання охоронних, рятувальних та евакуаційних робіт на будівлях та пам'ятниках, що пошкоджені; проведення робіт, що вимагають використання спеціалізованого технічного обладнання або вибухових речовин, які є в розпорядженні Збройних Сил РП; вивезення небезпечних матеріалів та їх знешкодження, використовуючи сили та ресурси Збройних Сил Республіки Польща; усунення хімічного забруднення, а також біологічного забруднення та інфекцій; видалення радіоактивного забруднення; виконання завдань, пов'язаних з ремонтом та реконструкцією технічної інфраструктури; участь у забезпеченні прохідності шляхів сполучення; надання медичної допомоги та виконання санітарних та протиепідемічних завдань.

Підрозділи Збройних Сил можуть бути передані у розпорядження воєводи у штатному складі або як цільові групи, створені спеціально. Правила поведінки спеціальних робочих груп та їх склад визначено у ст. 25в Закону [4].

Деталізованість реалізації положень Закону РП ми проаналізували на основі двох планів антикризового управління - плану антикризового менеджменту КуявськоПоморського та Поморського воєводств. 


\section{Науковий вісник : державне управління № 2(8) 2021}

ZADANIA I OBOWIĄZKI UCZESTNIKÓW ZARZĄDZANIA KRYZYSOWEGO W FORMIE SIATKI BEZPIECZEŃSTWA

2.1 ZESTAWIENIE ZAGROŻEŃ ZAWARTYCH W KATALOGU ZAGROŻEŃ ZE WSKAZANIEM PODMIOTU WIODĄCEGO ORAZ PODMIOTÓW WSPÓŁPRACUJĄCYCH

W Instytuja wiodąca $\quad$ P Instytuja pomocnicza

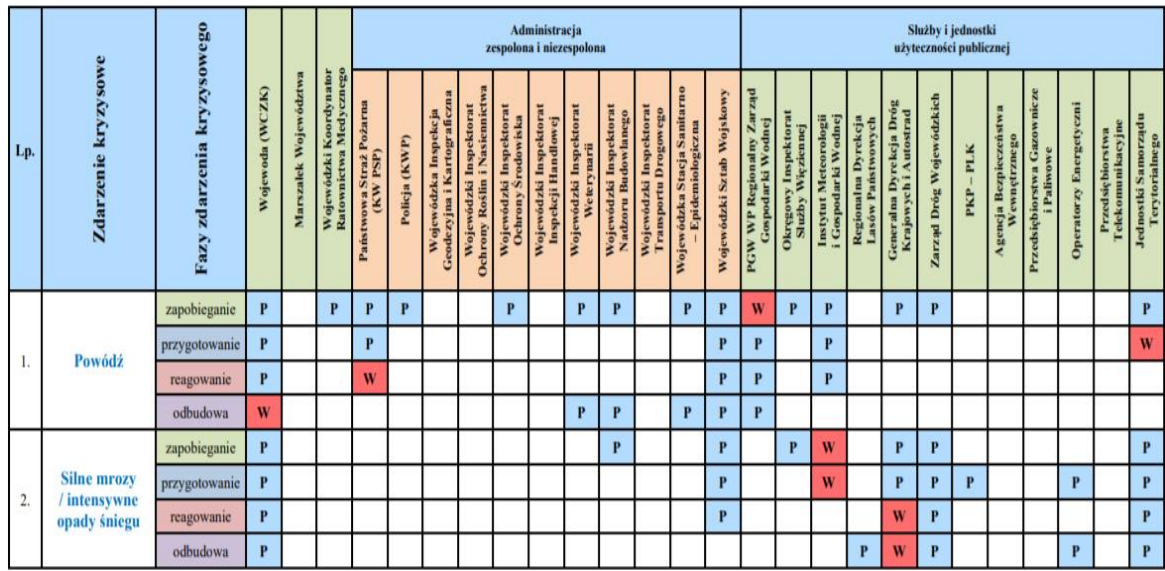

Рисунок 1 - Витяг з плану [41].

У частині першій (генеральний план) визначено характеристики небезпеки та ризик їх виникнення. Ретельно, в окремих розділах описані завдання та обов'язки учасників антикризового управління, визначено Мережу безпеки (приклад на рис. 1). Окремі основні розділи плану визначають сили та засоби, що заплановані для використання; завдання, що визначення в планах короткотермінових дій; завдання, щодо моніторингу загроз; порядок залучення запланованих сил та засобів; процедури реагування на визначені кризи, організацію співпраці із залученими силами, функціональні додатки щодо окремих операцій.

Цікавим досвідом для нас $є$ зміст розділів «Завдання та обов'язки учасників антикризового управління у вигляді мережі безпеки». Цей розділ зазвичай розробляється у вигляді мережі безпеки, розбитої на етапи управління кризовими ситуаціями. Мережа безпеки повинна містити загрози, визначені в каталозі, і вказують на суб'єктів, які беруть участь у виконанні завдань на окремих етапах процесу антикризового управління. Мережа 
безпеки також повинна вказувати орган управління, провідний суб'єкт господарювання в окремих видах загроз, а також співпрацюючі суб'єкти. Щоб бути прийнятним, як правило, для кожної загрози має бути вказано один провідний суб'єкт, тоді як кількість установ, що співпрацюють, необмежена і залежить від потреб та можливостей рівня, що організовує діяльність. В цьому розділі структурним елементом $\epsilon$ опис завдань та обов'язків провідних та співпрацюючих суб'єктів (за окремими видами загроз).

Окремим розділом визначається режим роботи воєводського центру антикризового управління за кожним видом загроз, завдання учасників антикризового менеджменту щодо моніторингу загроз (за кожним її видом).

\begin{tabular}{|c|c|c|c|c|}
\hline Czynności do wykonania & $\begin{array}{c}\text { Kierujący } \\
\text { działaniami }\end{array}$ & $\begin{array}{l}\text { Dokumentujący } \\
\text { przebieg działań }\end{array}$ & \begin{tabular}{|c|} 
Organizacja \\
$\begin{array}{c}\text { Współdziałania i obiegu } \\
\text { informacji }\end{array}$ \\
\end{tabular} & $\begin{array}{c}\text { Procedury komunikacji } \\
\text { społecznej }\end{array}$ \\
\hline \multicolumn{5}{|c|}{ 1. Wzmocnić osobowo całodobowy dyżur pelniony w ramach Wojewódzkiego Centrum Zarządzania Kryzysowego. } \\
\hline $\begin{array}{l}\text { - wyznaczyé z personelu Wydziału Bezpieczenistwa } \\
\text { i Zarządzania Kryzysowego osoby } \\
\text { do wzmocnienia dyżuru pełnionego w ramach } \\
\text { Wojewódzkiego Centrum Zarządzania } \\
\text { Kryzysowego (WCzK); } \\
\text { - opracować system (plan) wzmocnienia dyżuru } \\
\text { i zapewnić jego formalno-prawne } \\
\text { funkcjonowanie; } \\
\text { - zapewnić minimalne wymagania logistyczne } \\
\text { zabezpieczające funkcjonowanie wzmocnionego } \\
\text { dyżuru WCzK; } \\
\text { - zorganizować szkolenie dla personelu } \\
\text { stanowiącego wzmocnienie dyżuru w zakresie } \\
\text { zadań dyżuru i sposobu ich realizacji. }\end{array}$ & $\begin{array}{l}\text { Dyrektor Wydziału } \\
\text { Bezpieczeństwa } \\
\text { i Zarządzania } \\
\text { Kryzysowego. }\end{array}$ & & $\begin{array}{l}\text { W czasie wykonywania } \\
\text { zadania, współdziałanie } \\
\text { wystąpi w relacji Wydział } \\
\text { BziK - Biuro Kadr } \\
\text { i Organizacji w zakresie } \\
\text { opracowania formalno- } \\
\text { prawnych regut pełnienia } \\
\text { dyżuru, a w szczególności } \\
\text { ustalenie czasu pracy, } \\
\text { sposobu rekompensaty, } \\
\text { ustanowienie } \\
\text { odmiennego okresu } \\
\text { rozliczeniowego. }\end{array}$ & \\
\hline 2. Polecić kierownikom jednostek adm & acji przekazywa & informacji dotyczący & sytuacji w rejonie kryzysu o & lo dyżuru WCZK. \\
\hline $\begin{array}{l}\text { - zorganizować grę decyzyjną z szefami jednostek } \\
\text { administracji zespolonej oraz z osobami } \\
\text { funkcyjnymi urzędu wojewódzkiego, na temat } \\
\text { przekazywania wszelkich informacji z rejonu } \\
\text { kryzysu do dyżuru WCzk; }\end{array}$ & $\begin{array}{l}\text { Dyrektor Wydziału } \\
\text { Bezpieczenstwa } \\
\text { i Zarządzania } \\
\text { Kryzysowego }\end{array}$ & Dyżurny WCZK & $\begin{array}{l}\text { W ramach realizacji } \\
\text { zadania współdziałanie } \\
\text { zostanie zorganizowane } \\
\text { w relacji: WCZK a służby } \\
\text { dyżurne/operacyjne }\end{array}$ & \\
\hline
\end{tabular}

Рисунок 2 - Витяг із плану антикризового менеджменту [40].

Деталізація плану щодо конкретних дій, враховуючи зазначений основний метод - метод проекту, реалізується в розділі щодо переліку модулів, які розрізняються на модулі воєводи і модулі старост. Наведемо приклад, щодо модулю завдань воєводи з антикризового управління, включаючи захист критичної інфраструктури (рис. 2). У модулі у таблично- 
графічному вигляді розписуються Концепція діяльності, обов'язки посадових осіб, операційні умови виконання завдань, заявка на реагування (рис. 2), умови співпраці 3 іншими інституціями, бюджет виконання завдання, правові підстави.

«База сил та ресурсів, які планується використовувати у кризових ситуаціях». Цей документ - база даних про ресурси, якими можна користуватися у кризових ситуаціях. Ця база даних розробляється в електронному вигляді та на папері i постійно оновлюється.

Обсяг статті не дозволяє навіть перерахувати назви розділів плану, не говорячи вже про аналіз їх змісту. На перший погляд може скластися, що деякі підрозділи різних розділів плану повторюють один одного. Однак, кожний з них розширює та деталізує дії того чи іншого суб'єкта системи антикризового менеджменту.

Окремим розділом деталізації $є$ так звані функціональні додатки. На прикладі функціонального додатку «Організація комунікації між суб'єктами процесу реагування на кризи» покажемо, що такі додатки готуються в описовій формі та доповнюється, як в даному випадку схемою організації комунікацій у кризових ситуаціях. Опис повинен показувати, що основними ланками в обміні інформацією в цих ситуаціях $€$ Центри управління кризовими ситуаціями, чергові служби суб'єктів, що займаються діяльністю, та контактних пунктів у підрозділах місцевого самоврядування. В якості засобів зв'язку використовується стаціонарна та факсимільна телефонія, доповнена мобільною телефонією та електронною поштою. Незалежно від вищезазначених систем, кожен із суб'єктів, які беруть участь у кризових операціях, може i повинен використовувати власні системи зв'язку.

Висновки та напрями подальшого дослідження. Отже, проведений аналіз основного Закону та деяких планів антикризового менеджменту РП на територіальному рівні дозволяють стверджувати, що система антикризового менеджменту РП: має науково обгрунтовану чітку законодавчу базу у вигляді Закону РП «Про антикризове управління»; інтегрована в систему національної безпеки РП і є невід'ємною ii складовою; спрямована на попередження виникнення 


\section{Науковий вісник : державне управління № 2(8) 2021}

кризових ситуацій, а в разі їх виникнення - їх опанування за рахунок запланованих заходів, реагування та відновлення ситуації до кризи. Основою системи кризового менеджменту $є$ територіальна мережа безпеки.

Напрямом подальшого дослідження є компаративний аналіз систем антикризового менеджменту різних країн, вивчення кращих практик організації антикризового управління РП.

\section{Список використаних джерел}

1. Мудрак Лара Комунікація і криза як громадам протистояти викликам i успішно діяти в період кризи / Вебсайт «Децентралізація». URL : https://cutt.ly/3bXsfCx (дата звернення 15.05.2021).

2. Концепція управління ризиками виникнення надзвичайних ситуацій техногенного та природного характеру: розпорядження Кабінету Міністрів України від 22 січня 2014 р. № 37-p // База даних «Законодавство України» / BP України. URL : https://zakon.rada.gov.ua/laws/show/37-2014-\%D1\%80\#Text (дата звернення 15.05.2021).

3. Волянський П.Б., Гур`єв С.О., Соловйов О.С., Терент`єва А.В. Кризовий менеджмент і принципи управління ризиками в процесі ліквідації наслідків надзвичайних ситуацій : монографія. Вид. 2 виправ. та доповн. К.: Парлам. вид-во, 2021. 432 с.

4. Ustawy o zarządzaniu kryzysowym (Dz. U. z 2007 r., nr 89) / Webportal «Lexlege». URL : https://cutt.ly/FnftEsA (дата звернення 15.05.2021).

5. Система державного управління Республіки Польща: досвід для України / авт.-уклад. Х. М. Дейнега ; за заг. ред. Ю. В. Ковбасюка. К. : НАДУ, 2010. 48 c. URL : https://cutt.ly/bbXsceN (дата звернення 15.05.2021).

6. Рогуля А. Європейський досвід функціонування системи цивільного захисту населення у забезпеченні національної безпеки. Збірник наукових праць. 2015. Вип. 45 "Ефективність державного управління". C. 130-138. URL : https://cutt.ly/hnfyOzM (дата звернення 15.05.2021).

7. Чигринський В. А. Політико-правове проєктування та державне конструювання системи забезпечення національної безпеки республіки польща: уроки для України. Інвестиції: практика та досвід. 2020. № 1314. C. 143-150. DOI: 10.32702/2306-6814.2020.13-14.143

8. Нікіпєлова Є. М. Державне управління безпековою політикою Республіки Польща: досвід для України. Дис. ....канд. наук держ. упр.: 25.00.05. Національний університет цивільного захисту України. Харків, 2019. 286 c. URl : https://nuczu.edu.ua/images/topmenu/science/spetsializovani-vchenirady/DISNikipelova.pdf

9. Strategia bezpieczeństwa narodowego rzeczypospolitej polskiej 2014. Warszawa, 2014. 57 s. URL: https://www.bbn.gov.pl/ftp/SBN\%20RP.pdf (дата звернення 15.05.2021). 


\section{Науковий вісник : державне управління № 2(8) 2021}

10. Falecki J., Dylematy zarządzania kryzysowego [Dilemmas of crisis management in the Republic of Poland]. Wyższa Szkoła Humanitas. Sosnowiec, 2016. $320 \mathrm{c}$.

11. Zarządzanie kryzysowe w obliczu zagrożenia COVID-19 oznacza konieczność zaangażowania szeregu niezależnych umiejętności z różnych obszarów, w celu ułatwienia podjęcia odpowiednich decyzji przez najwyższe kierownictwo. Porady dotyczace zarzadzania kryzysowego / KPMG. URL : https://cutt.ly/xbXsTth (дата звернення 05.05.2021).

12. Swoboda Piotr Zarządzanie kryzysowe na poziomie lokalnym - wybrane aspekty teoretyczne i praktyczne dotyczące zagrożenia powodziowego. Wybrane problemy bezpieczeństwa tom II. Polsko - Butgarsko - Ukraińskie Prace Naukowe. Wydawca: Europejskie Stowarzyszenie Promocji Nauki i Rozwoju przy wspótpracy $z$ Wydziatem Politologii Uniwersytetu Pedagogicznego im. Komisji Edukacji Narodowej w Krakowie. Kraków 2018. S. 86-112. URL : https://cutt.ly/8bXsUne (дата звернення 05.05.2021).

13. Sienkiewicz-Małyjurek Katarzyna Smart City w budowaniu odporności miast na zagrożenia. Bezpieczeństwo : teoria i praktyka. Nr 4. 2020. Ss. 75-90 URL : https://cutt.ly/dnfyXKi (дата звернення 15.05.2021).

14. Kąkol Urszula, Marczewski Marcin Metody analizy i oceny ryzyka stosowane w zarządzaniu kryzysowym na poziomie gminnym. [Crisis Management, Risk Analysis and Assessment Methods on the Municipal Level] Zeszyty Naukowe Uniwersytetu Ekonomicznego w Krakowie Cracow Review of Economics and Management Location: Poland. Nr 11 (959). 2016. S. 53-69. URL : https://cutt.ly/TnfyNOT (дата звернення 05.05.2021).

15. Kisilowski Marek, Kunikowski Grzegorz Charakterystyka zagrożeń organizacyjno-prawnych i socjalnych objętych planami ratowniczymi oraz planami zarządzania kryzysowego na poziomie centralnym. Autobusy $\mathrm{Nr} 9$. 2017. S. 197-202. URL : https://cutt.ly/lbXsD2D (дата звернення : 05.05.2021).

16. J. Stawnicka and I. Klonowska, Krajowa Krajowa mapa zagrożeń bezpieczeństwa nową formą dialogu polskiej Policji ze społecznością lokalną na rzecz bezpieczeństwa wewnętrznego. [The National Map of Security Threats as a new form of dialogue between the Polish Police and the local community for internal security. Socio-pedagogical aspect], Wyższa Szkoła Humanitas Sosnowiec 2018. $130 \mathrm{c}$.

17. Płonka-Bielenin Katarzyna Propozycja zmian w zakresie zarządzania kryzysowego - uwagi de lege lata $\mathrm{i}$ de lege ferenda. Przegląd Prawa Publicznego. nr 7-8. 2020 ss. 153-165. URL : https://cutt.ly/WbXsXZ7 (дата звернення 15.05.2021).

18. Katarzyna Sienkiewicz-Małyjurek Wydział organizacji i zarządzania problemy organizacyjne zarządzania kryzysowego w samorządach. Zeszyty naukowe politechniki śląskiej. Seria: organizacja i zarządzanie z. 59. 2011. URL : https://cutt.ly/pbXsB14 (дата звернення 05.05.2021).

19. Kopczewski Marian Zintegrowany system ratowniczy elementem zarządzania kryzysowego. Zeszyty naukowe Państwowej Wyższej szkoły techniczno- 
ekonomicznej im. ks. Bronisława Markiewicza w Jarosławiu. Współczesne problemy zarządzania $\mathrm{Nr}$ 10. Bezpieczeństwo publiczne. 2017. S. 37-56. URL : https://cutt.ly/bbXsNKv (дата звернення 15.05.2021).

20. Górska Karina Zarządzanie kryzysowe jako istotny element kierowania współczesnym bezpieczeństwem narodowym. [Crisis management as an important component of national security management today]. Zeszyty Naukowe Uniwersytetu przyrodniczo-humanistycznego w Siedlcach Nr 97 Seria: Administracja i Zarządzanie. 2013. URL : https://cutt.ly/HbXs1Bw (дата звернення : 05.05.2021).

21. Korzecki Kazimierz, Pączek Wiesław Rządowe Centrum Bezpieczeństwa w krajowym systemie zarządzania kryzysowego. Geneza i ogólna charakterystyka. [The Government Centre in National Crisis Management System]. Przedsiębiorczość i Zarządzanie 6.1/2015. S. 137-154.

https://cutt.ly/0nfy8WD (дата звернення 15.05.2021).

22. Administracja publiczna $\mathrm{w}$ procesie zapewnienia bezpieczeństwa lokalnego. Bezpieczeństwo lokalne - wybrane aspecty : Monografe. Pod redakcją naukową Grzegorda Gorskiego, Andrzeja Potoczka. Współpraca wydawnicza: Wydawnictwo Edukacyjne „Akapit” s.c. oraz Jagielloński Instytut Wydawniczy Toruń 2020 URL : https://cutt.ly/EbXs9ZS (дата звернення 15.05.2021).

23. Kunikowski Grzegorz, Smagowicz Justyna, Uklańs Anna Zastosowanie metod i technik $\mathrm{w}$ procesach wspomagających proces zarządzania kryzysowego [Application of Methods and Techniques in Processes Supporting the Crisis Management Process] Nowoczesne Systemy Zarząazzania. 2019 nr 4 Ss. 83-97 URL : https://cutt.ly/QbXs4uy (дата звернення 15.05.2021).

24. Ciekanowski Zbigniew, Marjański Andrzej Uwarunkowania zarządzania kryzysowego na poziomie podstawowym. [Conditions of crisis management at the basic level] Zeszyty naukowe Państwowej Wyższej szkoły technicznoekonomicznej im. ks. Bronisława Markiewicza w Jarosławiu. Współczesne problemy zarządzania $\mathrm{Nr} 10$. Bezpieczeństwo publiczne. URL : https://cutt.ly/tbXs7NB (дата звернення 15.05.2021).

25. Sienkiewicz-Małyjurek Katarzyna Odporność i przedsiębiorczość w zarządzaniu kryzysowym. [Resilience and entrepreneurship in emergency management] Ekonomia Społeczna. 2/2020. Ss. 22-36. URL : https://cutt.ly/Bnfy52H (дата звернення 15.05.2021).

26. Wiśniewski B., Prońko J. Podstawowe problemy współpracy w zarządzaniu kryzysowym. Вісник Львівського державного університету безпеки життедіяльності 20 (Грудень), 2019. С. 29-35. URL : https://cutt.ly/lnfueJs (дата звернення 05.05.2021).

27. Żebrowski Andrzej Służby specjalne w systemie zarządzania kryzysowego państwem. Refleksje o przeszłości, spojrzenie na współczesność : Monografia poświęcona Profesorowi Sergiuszowi Wasiucie z okazji 60-letniego Jubileuszu i 35-lecia pracy zawodowej. Kraków 2018. S. 157-183. URL : https://cutt.ly/LbXdeI7 (дата звернення 15.05.2021).

28. Morawski Antoni Rola organizacji pozarządowych w procesie zarządzania 


\section{Науковий вісник : державне управління № 2(8) 2021}

kryzysowego. [Role of Non-Governmental Organizations in Emergency Management Process] Kwartalnik Naukowy OAP UW "e-Politikon". Ośrodek Analiz Politologicznych UW 2013. № 6 S. 187-207. URL : https://cutt.ly/ObXdtCv (дата звернення 15.05.2021).

29. Beskosty Małgorzata Funkcje i rola mediów w zarządzaniu kryzysowym [the functions and the role of media in crisis management]. Studia nad bezpieczeństwem. nr 3. 2018 ss. 187-198. URL : https://cutt.ly/8bXdu5z (дата звернення 15.05.2021).

30. Marjański Andrzej, Ropęga Jarosław Ochotnicze Straże Pożarne. Zapewnienie efektu synergii w zarządzaniu kryzysowym. Bezpieczeństwo. Teoria i Praktyka. 4/2019. Ss. 63-81 URL : https://cutt.ly/hnfuudQ (дата звернення 15.05.2021).

31. Derek Paweł Rola narodowych służb hydrologiczno-meteorologicznych w zarządzaniu ryzykiem kryzysowym związanym z katastrofami naturalnymi na przykładzie Instytutu Meteorologii i Gospodarki Wodnej - Państwowego Instytutu Badawczego / Repozytorium Uniwersytetu lodzkiego. Ss. 273-288 URl : https://cutt.ly/2bXdpnK (дата звернення 15.05.2021).

32. Zwierkowska Oliwia Relacja starosty $\mathrm{z}$ komendantem powiatowym państwowej straży pożarnej w stanie klęski żywiołowej [Relationship between the district head and the district commandant of the state fire service in the state of natural disaster] : pracy licencjackie. 2020-07-10. / Jagiellonian Uniwersity Repository. URL : https://ruj.uj.edu.pl/xmlui/handle/item/240949 (дата звернення 15.05.2021).

33. Zarządzanie kryzysowe NATO mechanizmem zapewniania bezpieczeństwa iochrony ludności.. [NATO Crisis Management as the Mechanism of Ensuring Security and Civil Protection] Przedsiębiorczość i Zarządzanie. 5.3/2017. S.341-357. URL : https://cutt.ly/BnfubCL (дата звернення 15.05.2021).

34. Świderski Andrzej W. Część II. Kultura bezpieczeństwa obywateli a funkcjonowanie systemu zarządzania kryzysowego w wymiarze lokalnym. Wyniki badań empirycznych [part II. Security culture of citizens and functioning of the crisis management system in the local dimension. The results of empirical research]. Wydawnictwo Naukowe UPH. Uniwersytet Przyrodniczo-Humanistyczny w Siedlcach. 268 s. URL : https://cutt.ly/abXddTE (дата звернення 15.05.2021).

35. Chrzan, T. Zarządzanie kryzysowe i zabezpieczenie przeciwpowodziowe na terenie powiatu kluczborskiego a poczucie bezpieczeństwa jego mieszkańców / Infona : portal komunicji naukowej. URL : https://cutt.ly/RbXdf8n (дата звернення 15.05.2021).

36. Andrzej Chodyński, Bezpieczeństwo w zarządzaniu publicznym. Wprowadzenie [Security in public governance: an introduction]. Bezpieczeństwo : teoria i praktyka. Nr 4. 2020. Ss. 13-16 URL : https://cutt.ly/unfuWWo (дата звернення 15.05.2021).

37. Pawłuszko Tomasz Projektowanie podręczników w naukach o bezpieczeństwie. Poszukiwanie dobrych praktyk. Rocznik Bezpieczeństwa Międzynarodowego 2020, vol. 14, $\mathrm{nr}$ 1. DOI : 


\section{Науковий вісник : державне управління № 2(8) 2021}

https://doi.org/10.34862/rbm.2020.1.3. URL : https://cutt.ly/JnfiLBC (дата звернення 15.05.2021).

38. Janusz Falecki, Organization of decision-making games in crisis management. Sosnowiec. 2015.

39. Stawnicka J., Klonowska I., Krajowa Mapa Zagrożeń Bezpieczeństwa w Polsce... [The National Map of Security Threats as a new form of dialogue between the Polish Police and the local community for internal security. Sociopedagogical aspect], Wyższa Szkoła Humanitas. Sosnowiec. 2018. 130 c.

40. Wojewódzki plan zarządzania kryzysowego (część b) / Pomorski Urzad Wojewodzki w Gdansku. URL : https://cutt.ly/VnfoaEK (дата звернення 15.05.2021).

41. Wojewódzki plan zarządzania kryzysowego / Kujawsko-Pomorski Urzad Wojewodzki w Bydgoszczy URL : https://cutt.ly/Enfol9j (дата звернення 15.05.2021).

42. G. Sobolewski, D. Majchrzak, Z. Sobejko, Uwarunkowania organizacji i funkcjonowania systemu zarządzania kryzysowego RP, Akademia Obrony Narodowej, Warszawa 2014, s. 68.

43. G. Sobolewski (kier. nauk.), Model zarządzania przepływem informacji w sytuacjach kryzysowych, Akademia Obrony Narodowej, Warszawa 2013, s. 7.

44. G. Sobolewski, Siły Zbrojne RP w zarządzaniu kryzysowym. Aspekt narodowy i międzynarodowy, Warszawa 2013, $321 \mathrm{~s}$.

45. Juliusz PIWOWARSKI, Mariusz ROZWADOWSKI System zarządzania kryzysowego jako element bezpieczeństwa narodowego ASO.A.7(1)/2016/344-3680.

\section{References}

1. Mudrak, Lara (2020) Komunikatsiia i kryza yak hromadam protystoiaty vyklykam i uspishno diiaty $\mathrm{v}$ period kryzy [Communication and crisis as communities meet challenges and act successfully in times of crisis] / Vebsait «Detsentralizatsiia». Retrieved from https://cutt.ly/3bXsfCx [in Ukrainian].

2. Kontseptsiia upravlinnia ryzykamy vynyknennia nadzvychainykh sytuatsii tekhnohennoho ta pryrodnoho kharakteru [The concept of risk management of emergencies of man-made and natural nature] : rozporiadzhennia Kabinetu Ministriv Ukrainy vid 22 sichnia 2014 r. № 37-r // Baza danykh «Zakonodavstvo Ukrainy» / VR Ukrainy. Retrieved from : https://cutt.ly/knfoEZA [in Ukrainian].

3. Volianskyi, P. B., Hur`iev, C. O., Soloviov, O.S., Terent ieva A. V. (2021) Kryzovyi menedzhment i pryntsypy upravlinnia ryzykamy $\mathrm{v}$ protsesi likvidatsii naslidkiv nadzvychainykh sytuatsii [Crisis management and principles of risk management in the process of emergency response] : monohrafiia. Vyd. 2 vyprav. ta dopovn. - K.: Parlam. vyd-vo. 432 s. [in Ukrainian].

4. Ustawy o zarządzaniu kryzysowym (Dz. U. z 2007 r., nr 89) / Webportal «Lexlege». Retrieved from https://lexlege.pl/ustawa-o-zarzadzaniu- 


\section{Науковий вісник : державне управління № 2(8) 2021}

kryzysowym/ [in Poland].

5. Systema derzhavnoho upravlinnia Respubliky Polshcha: dosvid dlia Ukrainy (2010) [The system of public administration of the Republic of Poland: experience for Ukraine] / avt.-uklad. Kh. M. Deineha ; za zah. red. Yu. V. Kovbasiuka. K. : NADU. 48 s. Retrieved from https://cutt.ly/bbXsceN [in Ukrainian].

6. Rohulia, A. (2015). Yevropeiskyi dosvid funktsionuvannia systemy tsyvilnoho zakhystu naselennia u zabezpechenni natsionalnoi bezpeky [European experience in the functioning of the civil protection system in ensuring national security]. Zbirnyk naukovykh prats. Vyp. 45 "Efektyvnist derzhavnoho upravlinnia". S. 130-138. Retrieved from https://cutt.ly/Hnfo2Wh [in Ukrainian].

7. Chyhrynsky, V. A. (2020). Polityko-pravove proiektuvannia ta derzhavne konstruiuvannia systemy zabezpechennia natsionalnoi bezpeky respubliky polshcha: uroky dlia Ukrainy [Political and legal design and state construction of the national security system of the republic of poland: lessons for Ukraine]. Investytsii: praktyka ta dosvid. 2020. № 13-14. S. 143-150. DOI: 10.32702/2306-6814.2020.13-14.143 [in Ukrainian].

8. Nikipielova, Ye. M. (2019). Derzhavne upravlinnia bezpekovoiu politykoiu Respubliky Polshcha: dosvid dlia Ukrainy [Public administration of the security policy of the Republic of Poland: experience for Ukraine]. Dys. ....kand. nauk derzh. upr. : 25.00.05. Natsionalnyi universytet tsyvilnoho zakhystu Ukrainy. Kharkiv, 2019. 286 s. Retrieved from https://cutt.ly/Tnfo5c2 [in Ukrainian].

9. Strategia bezpieczeństwa narodowego rzeczypospolitej polskiej 2014. $\begin{array}{lllll}\text { Warszawa, } & 2014 . & 57 & \text { s. } & \text { Retrieved }\end{array}$ https://www.bbn.gov.pl/ftp/SBN\%20RP.pdf [in Poland].

10. Falecki, J. (2016), Dylematy zarządzania kryzysowego [Dilemmas of crisis management in the Republic of Poland]. Wyższa Szkoła Humanitas. Sosnowiec, 2016. 320 c. [in Poland].

11. Zarządzanie kryzysowe w obliczu zagrożenia COVID-19 oznacza konieczność zaangażowania szeregu niezależnych umiejętności z różnych obszarów, w celu ułatwienia podjęcia odpowiednich decyzji przez najwyższe kierownictwo. Porady dotyczace zarządzania kryzysowego / KPMG. Retrieved from https://cutt.ly/xbXsTth [in Poland].

12. Swoboda, Piotr (2018) Zarządzanie kryzysowe na poziomie lokalnym wybrane aspekty teoretyczne i praktyczne dotyczące zagrożenia powodziowego. Wybrane problemy bezpieczeństwa tom II. Polsko Bułgarsko - Ukraińskie Prace Naukowe. Wydawca: Europejskie Stowarzyszenie Promocji Nauki i Rozwoju przy wspótpracy z Wydziałem Politologii Uniwersytetu Pedagogicznego im. Komisji Edukacji Narodowej w Krakowie. Kraków 2018. S. 86-112. Retrieved from https://cutt.ly/8bXsUne [in Poland].

13. Sienkiewicz-Małyjurek, Katarzyna (2020). Smart City w budowaniu odporności miast na zagrożenia. Bezpieczeństwo : teoria i praktyka. Nr 4. Ss. 
75-90 Retrieved from https://www.ceeol.com/search/viewpdf?id=962448 [in Poland].

14. Kąkol, Urszula, Marczewski, Marcin (2016). Metody analizy i oceny ryzyka stosowane w zarządzaniu kryzysowym na poziomie gminnym. [Crisis Management, Risk Analysis and Assessment Methods on the Municipal Level] Zeszyty Naukowe Uniwersytetu Ekonomicznego w Krakowie Cracow Review of Economics and Management Location: Poland. Nr 11 (959). 2016. S. 53 69. Retrieved from https://zeszytynaukowe.uek.krakow.pl/article/view/1204/915 [in Poland].

15. Kisilowski, Marek, Kunikowski Grzegorz (2017) Charakterystyka zagrożeń organizacyjno-prawnych i socjalnych objętych planami ratowniczymi oraz planami zarządzania kryzysowego na poziomie centralnym. Autobusy $\mathrm{Nr} 9$. 2017. S. 197-202 Retrieved from https://cutt.ly/lbXsD2D [in Poland].

16. Stawnicka, J. Klonowska, I. (2018), Krajowa mapa zagrożeń bezpieczeństwa nową formą dialogu polskiej Policji ze społecznością lokalną na rzecz bezpieczeństwa wewnętrznego. [The National Map of Security Threats as a new form of dialogue between the Polish Police and the local community for internal security. Socio-pedagogical aspect], Wyższa Szkoła Humanitas Sosnowiec. 130 c. [in Poland].

17. Płonka-Bielenin, Katarzyna Propozycja zmian w zakresie zarządzania kryzysowego - uwagi de lege lata i de lege ferenda. Przegląd Prawa Publicznego. $\mathrm{nr}$ 7-8. 2020 ss. 153-165. Retrieved from https://cutt.ly/WbXsXZ7 [in Poland].

18. Sienkiewicz-Małyjurek, Katarzyna (2011) Wydział organizacji i zarządzania problemy organizacyjne zarządzania kryzysowego w samorządach. Zeszyty naukowe politechniki śląskiej. Seria: organizacja i zarządzanie z. 59. Retrieved from https://cutt.ly/pbXsBl4 [in Poland].

19. Kopczewski, Marian (2017) Zintegrowany system ratowniczy elementem zarządzania kryzysowego. Zeszyty naukowe Państwowej Wyższej szkoły techniczno-ekonomicznej im. ks. Bronisława Markiewicza w Jarosławiu. Współczesne problemy zarządzania $\mathrm{Nr}$ 10. Bezpieczeństwo publiczne. 2017. S. 37-56. Retrieved from https://cutt.ly/bbXsNKv [in Poland].

20. Górska, Karina (2013) Zarządzanie kryzysowe jako istotny element kierowania współczesnym bezpieczeństwem narodowym. [Crisis management as an important component of national security management today]. Zeszyty Naukowe Uniwersytetu przyrodniczo-humanistycznego w Siedlcach Nr 97 Seria: Administracja i Zarządzanie. Retrieved from https://cutt.ly/HbXs1Bw [in Poland].

21. Korzecki, Kazimierz, Pączek Wiesław (2015) Rządowe Centrum Bezpieczeństwa w krajowym systemie zarządzania kryzysowego. Geneza i ogólna charakterystyka. [The Government Centre in National Crisis Management System]. Przedsiębiorczość i Zarządzanie 6.1/2015. S. 137-154. https://www.ceeol.com/search/article-detail?id=825166 [in Poland].

22. Administracja publiczna w procesie zapewnienia bezpieczeństwa lokalnego. Bezpieczeństwo lokalne - wybrane aspecty : Monografe. Pod redakcją 


\section{Науковий вісник : державне управління № 2(8) 2021}

naukową Grzegorda Gorskiego, Andrzeja Potoczka. Współpraca wydawnicza: Wydawnictwo Edukacyjne „Akapit” s.c. oraz Jagielloński Instytut Wydawniczy Torun 2020 Retrieved from https://cutt.ly/EbXs9ZS [in Poland].

23. Kunikowski, Grzegorz, Smagowicz, Justyna (2019) Uklańs Anna Zastosowanie metod $\mathrm{i}$ technik $\mathrm{w}$ procesach wspomagających proces zarządzania kryzysowego [Application of Methods and Techniques in Processes Supporting the Crisis Management Process] Nowoczesne Systemy Zarządzania. $2019 \mathrm{nr} 4$ Ss. 83-97 Retrieved from https://cutt.ly/QbXs4uy [in Poland].

24. Ciekanowski, Zbigniew, Marjański, Andrzej Uwarunkowania zarządzania kryzysowego na poziomie podstawowym. [Conditions of crisis management at the basic level] Zeszyty naukowe Państwowej Wyższej szkoły technicznoekonomicznej im. ks. Bronisława Markiewicza w Jarosławiu. Współczesne problemy zarządzania $\mathrm{Nr} 10$. Bezpieczeństwo publiczne. Retrieved from https://cutt.ly/tbXs7NB [in Poland].

25. Sienkiewicz-Małyjurek, Katarzyna Odporność i przedsiębiorczość w zarządzaniu kryzysowym. [Resilience and entrepreneurship in emergency management] Ekonomia Społeczna. 2/2020. Ss. 22-36. Retrieved from https://www.ceeol.com/search/viewpdf?id=958752 [in Poland].

26. Wiśniewski, B., Prońko, J. Podstawowe problemy współpracy w zarządzaniu kryzysowym. Вісник Львівського державного університету безпеки життедіяльності 20 (Грудень), 2019. С. 29-35. Retrieved from https://doi.org/https://doi.org/10.32447/20784643.20.2019.05 [in Poland].

27. Żebrowski, Andrzej (2018) Służby specjalne w systemie zarządzania kryzysowego państwem. Refleksje o przeszłości, spojrzenie na współczesność : Monografia poświęcona Profesorowi Sergiuszowi Wasiucie z okazji 60letniego Jubileuszu i 35-lecia pracy zawodowej. Kraków. S. 157-183. Retrieved from https://cutt.ly/LbXdeI7 [in Poland].

28. Morawski, Antoni (2013) Rola organizacji pozarządowych w procesie zarządzania kryzysowego. [Role of Non-Governmental Organizations in Emergency Management Process] Kwartalnik Naukowy OAP UW "ePolitikon". Ośrodek Analiz Politologicznych UW 2013. № 6 S. 187-207. Retrieved from https://cutt.ly/ObXdtCv [in Poland].

29. Beskosty Małgorzata (2018) Funkcje i rola mediów w zarządzaniu kryzysowym [The functions and the role of media in crisis management]. Studia nad bezpieczeństwem. $\mathrm{nr}$ 3. ss. 187-198. Retrieved from https://cutt.ly/8bXdu5z [in Poland].

30. Marjański, Andrzej, Ropęga, Jarosław (2019) Ochotnicze Straże Pożarne. Zapewnienie efektu synergii $\mathrm{w}$ zarządzaniu kryzysowym. Bezpieczeństwo. Teoria i Praktyka. 4/2019. Ss. 63-81 Retrieved from https://www.ceeol.com/search/viewpdf?id=877420 [in Poland].

31. Derek Paweł (2018) Rola narodowych służb hydrologicznometeorologicznych $\mathrm{w}$ zarządzaniu ryzykiem kryzysowym związanym $\mathrm{z}$ katastrofami naturalnymi na przykładzie Instytutu Meteorologii i Gospodarki Wodnej - Państwowego Instytutu Badawczego / Repozytorium Uniwersytetu 
lodzkiego. Ss. 273-288 Retrieved from https://cutt.ly/2bXdpnK [in Poland].

32. Zwierkowska Oliwia (2020) Relacja starosty z komendantem powiatowym państwowej straży pożarnej w stanie klęski żywiołowej [Relationship between the district head and the district commandant of the state fire service in the state of natural disaster] : pracy licencjackie. 2020-07-10. / Jagiellonian Uniwersity Repository. Retrieved from https://ruj.uj.edu.pl/xmlui/handle/item/240949 [in Poland].

33. Zarządzanie kryzysowe NATO mechanizmem zapewniania bezpieczeństwa iochrony ludności.. [NATO Crisis Management as the Mechanism of Ensuring Security and Civil Protection] Przedsiębiorczość i Zarządzanie. 5.3/2017. S.341-357. Retrieved from https://www.ceeol.com/search/viewpdf?id=734320 [in Poland].

34. Świderski Andrzej W. Część II. Kultura bezpieczeństwa obywateli a funkcjonowanie systemu zarząazania kryzysowego w wymiarze lokalnym. Wyniki badań empirycznych [part II. Security culture of citizens and functioning of the crisis management system in the local dimension. The results of empirical research]. Wydawnictwo Naukowe UPH. Uniwersytet Przyrodniczo-Humanistyczny w Siedlcach. 268 s. Retrieved from https://cutt.ly/abXddTE [in Poland].

35. Chrzan, T. Zarządzanie kryzysowe i zabezpieczenie przeciwpowodziowe na terenie powiatu kluczborskiego a poczucie bezpieczeństwa jego mieszkańców / Infona : portal komunicji naukowej. Retrieved from https://cutt.ly/RbXdf8n [in Poland].

36. Chodyński Andrzej (2020), Bezpieczeństwo w zarządzaniu publicznym. Wprowadzenie [Security in public governance: an introduction]. Bezpieczeństwo : teoria i praktyka. Nr 4. 2020. Ss. 13-16 Retrieved from https://www.ceeol.com/search/viewpdf?id=962418 [in Poland].

37. Pawłuszko Tomasz (2020) Projektowanie podręczników w naukach o bezpieczeństwie. Poszukiwanie dobrych praktyk. Rocznik Bezpieczeństwa Międzynarodowego, vol. 14, nr 1 DOI: https://doi.org/10.34862/rbm.2020.1.3. Retrieved from https://cutt.ly/zbX5jGr [in Poland].

38. Janusz Falecki, (2015) Organization of decision-making games in crisis management. Sosnowiec [in Poland].

39. Stawnicka J., Klonowska I. (2018) Krajowa Mapa Zagrożeń Bezpieczeństwa w Polsce... [The National Map of Security Threats as a new form of dialogue between the Polish Police and the local community for internal security. Sociopedagogical aspect], Wyższa Szkoła Humanitas Sosnowiec. 130 c. [in Poland].

40. Wojewódzki plan zarządzania kryzysowego (część b) / Pomorsk

i Urzad Wojewodzki w Gdansku. Retrieved from https://cutt.ly/MbX5gg1 [in Poland].

41. Wojewódzki plan zarządzania kryzysowego / Kujawsko-Pomorski Urzad Wojewodzki w Bydgoszczy Retrieved from https://cutt.ly/Enfol9j [in Poland].

42. G. Sobolewski, D. Majchrzak, Z. Sobejko (2014) Uwarunkowania organizacji i funkcjonowania systemu zarządzania kryzysowego RP, Akademia Obrony 


\title{
Науковий вісник : державне управління № 2(8) 2021
}

Narodowej, Warszawa. s. 68 [in Poland].

43. G. Sobolewski (kier. nauk.) (2013), Model zarządzania przepływem informacji w sytuacjach kryzysowych, Akademia Obrony Narodowej, Warszawa. s. 7.

44. G. Sobolewski (2013) Siły Zbrojne RP w zarządzaniu kryzysowym. Aspekt narodowy i międzynarodowy, Warszawa. 321 s. [in Poland].

45. Juliusz Piwowarski, Mariusz Rozwadowski System zarządzania kryzysowego jako element bezpieczeństwa narodowego ASO.A.7(1)/2016/344-3680 [in Poland].

\section{CRISIS MANAGEMENT IN THE REPUBLIC OF POLAND: OVERVIEW OF THE BASIC LAW AND PRACTICE OF ITS APPLICATION AT THE TERRITORIAL LEVEL OF THE PUBLIC ADMINISTRATION}

\author{
Borysov Andrii, Lytvynovskyi Yevhen
}

\begin{abstract}
The unpredictability and rapid changeability of modern threats, their global nature make security one of the most important problems of today's and future world. The introduction of European standards and Ukraine's integration into the EU require transformations in all spheres of Ukrainian society. Such transformations in the management system of the Unified State Civil Protection System, taking into account the need to implement the Concept of Risk Management, are the need to develop mechanisms of state regulation in the field of risk management. However, the implementation of modern principles of anticrisis management in Ukraine is slow. Scientists are trying to develop the latest organizational and managerial approaches to solving problems of emergency risk management. However, the experience of crisis management in the Republic of Poland (hereinafter - RP) was left out of consideration, where its foundations are quite thoroughly defined at the legislative level, and the practice of implementing its principles dates back more than 13 years. Review of the Law of the Republic of Poland "On Crisis Management" and the practice of its application at the territorial level in terms of developing plans for anti-crisis management is a scientific task of our study and is covered in this article. The main research method is content analysis of the main Law of the Republic of Poland "On Crisis Management" and analysis of the content of crisis management plans. Literary search of publications of Polish scientists on anti-crisis management was also used. In the main content of the article: it is emphasized that the Concept of anti-crisis management, which is enshrined in the Law of the Republic of Poland, focuses on the principle of primacy of the territorial system; the conceptual and terminological apparatus defined in it is analyzed; anti-crisis management plans at the voivodship level are analyzed. The article defines the principles of building a crisis anti-management system, features of the crisis management system at different levels of government; it is concluded that it is integrated into the national security system, which structurally has management subsystems, an executive subsystem and a
\end{abstract}




\section{Науковий вісник : державне управління № 2(8) 2021}

support subsystem; It is argued that much attention in the system of crisis management is paid to the organization of cooperation, crisis communications between all levels of government. To do this, a security network is being created, which is relevant for improving the system in Ukraine. The functioning of the system is primarily aimed at preventing crises, and in case of their occurrence taking control of their development, based on planned measures, minimizing and eliminating the consequences and restoring the functioning of pre-crisis society. The key element that is legally defined and structurally prescribed in the Law is the phase of preparation of the anti-crisis management system of the RP. The analysis of anti-crisis management plans shows that they prescribe in detail all threats, operations for their monitoring, minimization, forces and means, the order of cooperation. The content of the plans of the national, voivodship, county levels, commune level and communal level is integrated in terms of the organization of coordination of activities, assistance and support to the lower level of government. In the interests of crisis management, the armed forces of the RP can be used, special groups consisting of the police, the state fire service, etc. can be created. Given the main method of management in the crisis management system, the method of project management, the plans develop action modules to prevent and respond to each threat. In the conclusions, it is noted that the dominant component of the anti-crisis management system is its territorial level of governance, which is carefully planned, threat monitoring and training of forces and means. The direction of further research is a comparative analysis of crisis management systems of different countries, the study of best practices in the organization of crisis management in the RP.

Keywords: crisis management, the Law of the Republic of Poland "On Crisis Management", planning, security network, response module, monitoring module, risk management concept, project management. 